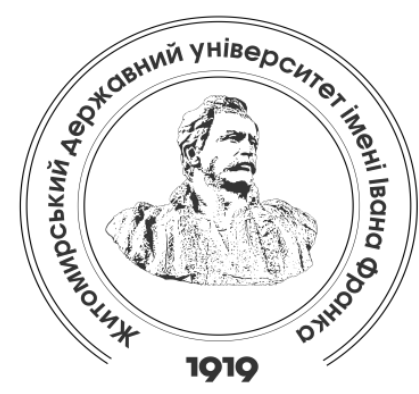

Zhytomyr Ivan Franko State University Journal. Philosophical Sciences. Vol. 1(87)

Вісник Житомирського державного університету імені Івана Франка. Фімософські науки. Вип. 1(87) ISSN: $2663-7650$

\title{
ANTHROPOLOGICAL DISCOURSE OF ORTHODOXY IN THE CONTEXT OF EXISTENTIAL UNCERTAINTY OF MODERN HUMAN BEING
}

\author{
O. L. Sokolovskyi, S. O. Shkil, G. P. Rozbytska*
}

The article analyzes the vector of modern transformation of anthropological issues in Orthodoxy, which determines the revision of traditional approaches to the conditions of worship, rites and ceremonies. Among the important conditions of modern religious transformations are considered general civilizational shifts due to the transition to postmodern society, world globalization, the crisis of European civilization, the process of secularization, the pandemic COVID19. These processes have led to the general "anthropological revolution" that the world community is experiencing today, while actualizing both existential problems and understanding the risks and difficulties of overcoming the pandemic. It has been established that the challenge for the Orthodox Churches is to demonstrate the stability of the faith and to adapt quickly to the realities of today on the basis of ecclesiology.

It is proved that the knowledge of the essence of man, in accordance with the existential challenges of today, necessitates theological discourse, rethinking, and the need for a new interpretation of the main issues of ritual practice. Anthropological provisions of Orthodox doctrine, which reveal the nature of man, his purpose in life and ways of salvation, are formed on the basis of Christian dogmas of triadology and Christology, where it is understood as the image and likeness of God. The authors come to understand and interpret the laws of transformation of Christian anthropology, due to the rethinking of the basic dogmatic provisions of the Orthodox faith and sociocultural breakdown of the modern world. Modern theologians draw an important conclusion for the understanding of the individual about the ontological primacy of the incarnation and the person in relation to nature and essence.

*Doctor of Sciences (Philosophy), Associate Professor of the Department of Philosophy and Political Science

(Zhytomyr Ivan Franko State University, Zhytomyr, Ukraine)

osokol_83@ukr.net

ORCID: 0000-0003-2228-3040

Doctor of Sciences (Philosophy), Professor, Professor of the Department of Philosophy

(National University of Life and Environmental Sciences of Ukraine, Kyiv, Ukraine)

lauby@meta.ua

ORCID: 0000-0003-3859-816X

Postgraduate Student at the Department of Philosophy and Politology

(Zhytomyr Ivan Franko State University, Zhytomyr, Ukraine)

galarozz7@icloud.com

ORCID: 0000-0002-8464-6516 
We believe that in a situation of existential uncertainty and variability of modern human existence, the most controversial issue in the Orthodox environment in practice is the interpretation of the sacrament of the Eucharist, which actualizes the issue of Christian dualism. Understanding it in the context of historical and modern trends requires reference to the Holy Father's heritage. This led to the emergence of syncretic religious movements in the early Christian period, expressing a dualistic interpretation of the person of Jesus Christ. This helps a person to overcome the theoretical limits of teaching, directing him to the knowledge of his true nature. The study focuses on the need to determine the anthropological content of paradigmatic transformations of modern Orthodox theology. As well as establishing the possibility of the influence of Christian doctrine of man on overcoming the anthropological crisis of our time. This approach in theology determines the view of the doctrine of man not only as theoretically significant, but also as a practical embodiment of the idea of godlikeness.

Keywords: Orthodox Anthropology, Christology, Soteriology, Man, Theology, Spirituality, Existential Uncertainty.

\section{АНТРОПОАОГІЧНИЙ ДИСКУРС ПРАВОСААВ'Я У КОНТЕКСТІ ЕКЗИСТЕНЦІЙНОЇ НЕВИЗНАЧЕНОСТІ БУТТЯ СУЧАСНОЇ АЮДИНИ}

\section{О. А. Соколовський, С. О. Шкімь, Г. П. Розбицька}

У статті проаналізовано вектор сучасної трансформащії антропологічної проблематики у православ'ї, який зумовлюе перегляд традииійних підходів до умов проведення богослужіння, обряду та иеремонії. Серед важливих умов сучасних релігійних трансформаиій розглядаються загальноиивілізаиійні зрушення, зумовлені переходом до постмодерного суспільства, світової глобалізації, кризою європейської иивілізації, прочесом секуляризації, пандемії COVID-19. Зазначені процеси призвели до загальної "антропологічноі революиії", яку съогодні переживає світова спільнота, актуалізуючи водночас як екзистениійні проблеми, так і осмислення ризиків й труднощів подолання пандемії. Встановлено, ше викликом для православних иерков є демонстрація стійкості віри і швидке пристосування до реалій съогодення на засадах еклезіології.

Доведено, шо пізнання сутності людини, відповідно з екзистениійними викликами съогодення, зумовлюе необхідність теологічного дискурсу, переосмислення, а нерідко й нового тлумачення основних питань ритуальної практики. Антропологічні положення православного віровчення, які розкривають природу людини, ї мету життя та шляхи спасіння, формуються на основі християнських догматів тріадологї та христологї̈, де ії осмислено як образ $i$ подобу Бога. Автори виходять у розумінні, інтерпретаиї із закономірностей трансформаиії християнської антропологї̈, зумовленої переосмисленням основних догматичних положень православного віровчення та соиіокультурного зламу сучасного світу. Сучасні богослови здійснюють важливий для розуміння особистості висновок про онтологічну первинність іпостасі та особи у відношенні до природи й сутності.

Вважаємо, шзо в ситуаиії екзистениійної невизначеності та мінливості буття сучасної людини найбільш дискусійним питанням у православному середовищі на практиці залишаеться трактування тайнства Свхаристії, яке актуалізуе проблематику християнського дуалізму. Ї̈ осмислення у контексті історичних $і$ сучасних тендениій потребуе звернення до святоотиівської спадшини, яка викликала появу $в$ ранньохристиянський період синкретичних релігійних рухів, виражаючи дуалістичну інтерпретаиію особи Ісуса Христа. Це допомагає людині подолати теоретичні межі вчення, спрямовуючи ї̈ до пізнання своєї реальної сутності. У дослідженні акцентована увага на необхідності визначення антропологічного змісту парадигмальних перетворень сучасної православної теологї̈. А також встановлення можливостей впливу християнського вчення про людину на подолання антропологічної кризи сучасності. Такий підхід у теологї̈ зумовлює погляд на вчення про людину не лише як теоретично значуще, а й як практичне втілення $y$ життя ідеї богоподібності. 
Ключові слова: православна антропологія, христологія, сотеріологія, людина, теологія, духовність, екзистениійна невизначеність.

Introduction of the issue. In the context of today's realities, the religious world has faced new challenges, necessitating a revision of traditional approaches to the conditions of ritual and ceremonies. The most controversial issue in practice in the Orthodox environment was the interpretation of the sacrament of the Eucharist, which leads to Christian dualism. In particular, individual local churches, as independent, self-governing parts of the Ecumenical Orthodox Church, have noted the need to preserve the distribution of gifts among believers in the sacrament of Holy Communion, as the bread and wine in the cup are the Body and Blood of Christ that heal the Christian soul and body. Based on this, the idea is introduced into religious and social discourse that the fear of contracting the COVID-19 virus is unfounded, because sickness and death cannot come from Christ, but only healing and rebirth. The Orthodox believer found himself in a situation of deep internal existential conflict. This involves choosing to call on Christ to join His Body and Blood, exposing oneself to the risk of contracting an infectious disease, or to reject it for fear of one's own safety and that of one's loved ones.

The first choice is based on the belief that during communion a bowl or spoon conveys the healing properties of Christ and therefore cannot be the conductor of disease. Particular attention is paid to the covering of dishes made of precious metals, which protects the surface from the virus and the person has a lower risk of disease. It is noted that liturgical wine has a certain antibacterial property capable of instant destruction of dangerous pathogens. Therefore, according to the clergy, the form and substance of gifts when using liturgical utensils are by their nature safe from infection. In this case, the danger of air that carries the infection is recognized.
And thus people who partake of the sacrament understand that can harm themselves. At such a critical time, the priest's use of the sacrament with a disposable spoon was introduced into practice as an attempt to help reduce the feeling of the test of faith. This approach is interpreted as recognizing the fragility of human nature in order to reduce tensions in temples and to take a public stand in the field of health care.

In order to prevent the wide and rapid spread of infectious diseases, most Orthodox churches reject this approach. Referring to the humility of the church to those people who do not belong to Orthodoxy, the bishops make every effort not to harm them. A new theological paradigm for Orthodoxy has been formulated, which fully corresponds to the very essence of Christianity as a creed. The main postulate is based on Orthodox Christology, substantiating the ontological identity of the human body with the resurrected body of Christ. Determining equal participation in general human nature, the virus, as part of God's creation, could live in the body of Christ even after His resurrection. The main difference is that dangerous microorganisms could not kill him. However, they can have negative consequences for the human body because it has not yet risen. In this case, the viral infection can be transmitted through the sacrament of Holy Communion, because it is part of God's creation, not an ontological evil. Representatives of this approach base their reasoning on the experience of ideological contradictions in the question of the hypostatic unity of the human and divine nature of Jesus Christ. Understanding this issue in the context of historical and modern trends requires reference to the Holy Father's legacy. This led to the emergence of syncretic religious movements in the preNicene period, which expressed a 
dualistic interpretation of the person of Jesus Christ.

The purpose of the article is to study the transformation of Orthodox anthropology as a component of theology. This involves an analysis of both early Christian syncretic religious movements and modern theologians who have expressed a dualistic interpretation of the person of Jesus Christ. The works of leading philosophers, theologians and theologians (K. Govorun, C. Ware, J. Ziziulas) are devoted to the philosophical and religious understanding of evolutionary processes in modern Orthodox theology. A thorough analysis of the anthropological dimensions of Orthodoxy in the context of the relationship with Christology was carried out by T. Gavrilyuk, V. Rubskyi, S. Shkil, O. Sokolovskyi.

Results and discussion. In the history of theological thought in different periods there were various religious movements, the doctrinal principles of which are associated with the denial or specific interpretation of the essence of Christ. One of the first such trends at the end of the first century was Docetism, the origins of which are connected with the worldview of the Hellenistic man and his dualistic ideas about the world, with a sharp opposition of spirit and flesh, world and Deity. The idea that God could incarnate, take on human form, suffer and die was unacceptable to the consciousness of man at that time. Therefore, many people in accordance with their views, converted to Christianity and have philosophical knowledge, sought to explain the Christian faith. It was the reaction to the mentioned requests of neophytes that the doctrine of Docetism became. Within this direction, two approaches have been formed in understanding and interpreting the nature of Christ: materialistic and formal.

The main idea of materialist Docetism was reduced to the denial of the human essence of Christ, depicting Him as a ghost, which at the meeting was marked in the human mind by its divine essence. The source of such ideas was the GrecoOrientalist position that the Divine Being cannot suffer. Similar ideas are also found in the New Testament and in the teachings of Ignatius (II century), who protested against ungodly people, claiming that Jesus suffered only in phantom. To confirm the truth of his teaching, the doctrines quoted the words of the Apostle Paul from the Holy Scriptures: "God sent His Son in the likeness of the flesh of $\sin$, a sin offering, and condemned the sin of the flesh" (Romans 8: 3). They saw in the phrase "in the likeness of sinful flesh" the evidence that Christ had only flesh similar to human flesh, but in fact did not have it, or had heavenly flesh different from human flesh [1: 106]. This idea was widespread in apostolic times and lasted until the end of the second century.

The struggle against Docetism occupies an important place in the theology of the Christian church, because this doctrine contradicts the main content of the apostolic sermon on faith in the death and resurrection of Christ. Salvation is based on a historical event witnessed by the apostles. Docetists denied death and resurrection, believing that salvation was related to abstract teaching, not to the actions of Christ [2]. In contrast, the Christian apologist Irenaeus refuted the Christological doctrine of Docetism, arguing that Christ must be human in order to redeem us from corruption and make us perfect [3: 374-375].

Materialistic Docetism, depending on the religious group that professed it, is presented in various forms. Ancient theologians, including Epiphanius of Cyprus, single out the currents in which Docetism was an integral feature of Christological teaching - Judeo-Christianity and Gnosticism. Representatives of the first movement were Jewish Christians who strictly adhered to the rites and customs of Judaism. Gnostics usually 
disguised various philosophical ideas in Christian terminology [4: 116].

The dualistic position in Christology was most fully reflected in the teachings of one of the currents of Gnosticism - the office, which is presented in the form of three special systems. The first is based on the Ebionite Christology of Adaptism, in which Jesus is seen as an ordinary person in a transcendent relationship with the aeon of Christ (Irenaeus and Justin). The second system was based on the Christological teaching of extreme Docetism, depicting Jesus as the ghost of a man who fulfills the mission of saving all living beings in the image of Christ (Gnostics and Varveliots). According to the third, Christ is the embodiment of the divine triad, who appeared before mankind in a special celestial body in the image of Jesus (Siphians, Perats and Naassens).

In the worldview system of offices, the Christological problem becomes of paramount nature. Christ occupies a central place in the history of mankind, giving Christianity the status of a world religion, which will save it from a sinful life. However, proclaiming the thesis of the universal and absolute significance of the person of Christ and His activities in the spirit of orthodox Christianity, the Ophites in their Christological and soteriological teachings returned to pagan concepts in ontological, cosmological, epistemological issues related to the problem of Christology.

The central idea of the Christology of the Ophites is based on the opposition of Christ and the Demiurge, which in their teaching develops in a logical sequence. On this basis, an apocalyptic concept of the descent of Christ and the overthrow of the kingdom of the Demiurge, immersed in matter, was built. The eschatology of the Ophites actually echoes Christianity's idea of the victory of the spirit over the flesh, freeing intelligent beings from the power of the material principle conditioned by the will of the Demiurge as the law of cosmic life. According to the teachings of the
Ophites, the spiritual substance of man after entering the human body decreases in its spiritual energy [5: 265]. The purpose of Christ's coming is to stop the process of further spiritual decline of intelligent beings. The instrument of the spiritual authority of Christ is preaching and asceticism, as the law of the new spiritual life of man in Christ. These views develop in soteriology, where they receive a rationale and reveal the Christology of movement.

Extreme spiritualism, inherent in the soteriology of the Ophites, led to the denial of the corporeal essence of Christ, as opposed to the cosmic realm of the Demiurge. Christ, as the embodiment of the "pure spirit" in man, is himself a spirit. However, the attempt to connect the spiritual person of Christ with His preaching activity has led to a number of inconsistencies in the doctrine that contradict their Christological assertions. In particular, the Ophites, allowing the incarnation of Christ in the human body, formed another form of idea of Him as a ghost in the flesh [6: 287]. Thus, the Christology of the Ophites was in fact reduced to Docetism, which they themselves condemned. Only one of the currents of the movement, the Ophitespessimists, in their Christology consistently adhered to the doctrinal doctrine, considering human nature in Christ as a ghost devoid of corporeality.

Thus, Christ in the understanding of the representatives of all directions of Ophitism is a teacher of truth. Extreme religious intellectualism in the teachings of the Ophites has all the hallmarks of mysticism, in which abstract contemplation is recognized as a source of religious and moral inspiration and the only means of communication with the deity. According to the Ophites, this state of mind leads to union with the divine Pleroma. The Ophit's movement is considered to be the earliest form of Gnosticism, which ideologically influenced the teachings of antiTrinitarian religious organizations. 
The last period of development of Gnosticism is associated with the emergence of the Manichaean movement, the founder of which was the Persian Mani. Manichaeism was a syncretic religion that absorbed elements of Zoroastrianism, Christianity, Gnosticism, and Buddhism. However, some researchers point to "not the Buddhist, but the ancient origin of the idea of the rebirth of "metepsychosis"' [7: 446]. The basis of this religious system was ancient Iranian dualism, in which cosmology, Christology, soteriology and eschatology are closely intertwined. The Manichaean believed that there were two equal substances and gods - spirit and matter, Good and Evil - who established two separate kingdoms with their own eons of light and darkness. The realm of darkness is filled with constant divination and war. However, seeing the bright kingdom, they formed an alliance to capture it. To confront them, God created man, but he perished in this struggle, the particles of his light came under the power of darkness, which mingled with matter, creating a patient Jesus. To release the light, God emanates from himself the living Spirit, who releases some of the elements of light, creates from them the sun and the moon, and places the impatient Jesus on the lights. Some elements of light still remain with matter. The living spirit creates the cosmos, which is beneficially influenced by the impatient Jesus and draws new particles of light to the sun. Eons of darkness created Adam from space to fight the elements of light. Then the impatient Jesus descends to earth to show people the way of salvation. However, the disciples did not properly understand His teachings and interpreted them at their own discretion. Anticipating this development, Christ promised to send a new Master who came in the form of Mani in order to unite people under the banner of returning to the true faith. Regardless of the geography of preaching and conversion, Manichaeism retained its main idea that "Mani, following the Apostle Paul, called himself a disciple of Jesus Christ" [8: 246].

Soteriology in Manichaeism is reduced to maintaining cleanliness of hands, mouth, and womb. He who keeps them intact is the chosen one, and after death he enters the realm of light. He who does not withstand this is subjected to more severe trials until he becomes perfect. At the end of the cleansing process, the visible world will be destroyed by fire. The Manichaean denied the old Testament, and the New was considered partly interpreted under the influence of an evil spirit in favor of Judaism.

During the Ecumenical Councils, the dualistic interpretation of the person of Jesus Christ found its reception in the teachings of Archimandrite Eutychius of Constantinople, who is considered the founder of Monophysitism. During the archbishopric of Dioscorius, a monk from Constantinople, Eutychius, opposed the decision of the Council of Ephesus. In his teaching, he referred to the formula of Cyril of Alexandria "one nature of God, the Word is embodied", replacing the word "embodied" with "connected". Therefore, the main idea of Christology Eutychius was to state that before the union in Jesus Christ there were two natures, and after only one [9: 228]. Eutychius believed that in the incarnation the Divine and human nature meet and it is in the union that the absorption of human nature by the Divine takes place. In his opinion, there is no point in talking about the human essence in Christ. Christ truly took on human nature; therefore, it is possible to assert the two natures of Christ before his union, but after the union there was only one nature of Christ - the Divine [10: 606]. Thus, the Monophysites professed that Christ was God and that His human form was illusory. Eutychius is credited with the idea that the human nature of Christ, dissolved in the Divine, lost its existence. 
In the teachings of Eutychius Dioscorius saw an active follower of Alexandrian theological thought, and gave him full support. Even in his sermons he not only repeated the teachings of Eutychius, but also tried in every way to propagate it in the church environment. The church clergy saw in the doctrine of Dioscorius and Eutychius an argument that directly contradicted the Christian position approved by the previous Ecumenical Councils. Any accusation of Dioscorius and Eutychius in propagating ideas incompatible with the Christian religion was harshly challenged and interpreted as the spread of Nestorianism [11: 88]. Dioscorius realized that the respect and authority of Cyril served as a reliable protection for him from various accusations. This gave him the impetus to gain fame and weight in the theological milieu, thus intensifying his polemical rhetoric.

However, during the Council of Constantinople in 448, the teaching of Eutychius was condemned under the presidency of Bishop Flavian. He strongly rejected the doctrine of the two natures in Christ, for this, in his view, contradicts the Scriptures and the teachings of the Church Fathers: "I read Blessed Cyril, the Holy Fathers and St. Athanasius: they recognized two natures before the union, and after the union and incarnation they recognized not two, but one" [12: 80]. The teachings of Eutychius, which rejected the term "one with us," led to the conclusion that the human nature of Christ was only imaginary for him. Therefore, according to most theologians, he preached a Docetic model of Christology. From the statement about two natures before connection and only one after connection the conclusion is made: either the two natures had to merge into something third or the Divine nature absorbed the human [11: 89].

Thus, in the middle of the V century, the preconditions were formed. They demanded that Christian theologians take decisive action to resolve the Christological question, around which there were constant manipulations of various church figures. Monophysitism was a special danger for the Christian church during this period. Followers have skillfully distorted the texts of Scripture and previous Ecumenical Councils, defending their theological positions and denying the oneness of Christ and humanity.

At the turn of the XX-XXI centuries human civilization is characterized by the rapid development of information technology, which radically changes the second nature. Information technology reveals the prospects of learning about the world around us and gives birth to a new person. The anthropological turn of the twentieth century became a vivid expression, which was reflected in the religious anthropology of Orthodoxy.

Modern theologians J. Ziziulas [13], C. Ware [14], K. Govorun [15], and V. Rubskyi [16] make a significant contribution to the development of Orthodox theology. They made an attempt to comprehend the basic Christian principles to the demands of today. In his works, J. Ziziulas raises a number of Christological questions, offering a kind of "Christological ecclesiology". We note that the Christological views of J. Ziziulas are revealed in the Trinitarian understanding of the nature of the Church. The theologian himself considers his ecclesiological system in two aspects: Christological and pneumatological. These aspects, according to J. Ziziulas, are inseparable in Christian doctrine.

The synthesis of Christology and pneumatology is objective in nature and is not an artificial product of theological constructions. In the liturgy, according to the theologian, these two approaches are clearly expressed in the relationship between baptism and anointing. Given the church's practice of anointing after baptism, there is every reason to believe that pneumatology is primary in relation 
to Christology. However, these sacraments of the Christian church are combined in the liturgical synthesis in a theological way, which removes the question of superiority.

The main problem for the Church, according to $\mathrm{J}$. Ziziulas, is the rupture of the synthesis between Christology and pneumatology in liturgical practice and theology. The consequence of such separation for the Catholic Church was not only the liturgical distinction between baptism and anointing, but also the dominance of Christology over pneumatology. The Orthodox Church has preserved the unity of the sacraments at the liturgical level, but this has not solved the problem of relations between the churches. The dominance of Christology over pneumatology in the Western tradition and pneumatology over Christology in the Eastern tradition leads to the definition of different accents and priorities in the theological and cultic approaches of the churches. This problem is closely related to ecclesiology, as it directly depends on the solution of previous aspects of theology.

In an attempt to solve this problem, the Christological views of J. Ziziulas are revealed, which are closely connected with Triadology: Where the Son is, there is also the Father and the Holy Spirit, and where the Spirit is, there is also the Father and the Son. Yet the contribution of each of these Persons of God to the economy is characterized by notable features of direct significance to the ecclesiology in which they are to be reflected [13: 131-132].

Since God knows His creation as the fulfillment of His will, it is not being, but the will of God's love that unites all beings and points to the meaning of being. It is in this aspect that the Christological problem of incarnation is revealed. According to J. Ziziulas, the incarnate Christ is so similar to the highest will of God's love that the incarnate Christ is the meaning of all created being and the goal of history. The creation of all things was done with Christ in the heart, so, despite the fall of man, the incarnation had to take place. From this J. Ziziulas concludes: "Christ incarnate is truth because he is the highest, unquenchable will of the ecstatic love of God, Who intends to bring everything created into communication with His own life to the knowledge of Him and of Himself in this event of communication" [13: 98].

The unity of Christology and pneumatology, according to J. Ziziulas, is manifested in the liberation of the Son by the Spirit and economy from the dependence of history: "If the Son died on the cross, thus submitting to historical existence, it was the Spirit who raised him from the dead. The Spirit exists outside of history, and when $\mathrm{He}$ acts in history, He does so in order to bring the last days, the eschaton, into the course of history" [13: 132]. Thus, the Spirit makes Christ an eschatological being, which in theology is referred to as the "New Adam".

J. Ziziulas points to another important aspect of the action of the Holy Spirit in the events of Christ. The participation of the Holy Spirit in economy, according to the theologian, makes Christ not just an individual, not "one" but "many". Therefore, the "collective personality" of Christ cannot be conceived without pneumatology, which introduces the dimension of communication into Christology. This is what allows J. Ziziulas to single out the Christological aspect in ecclesiology in the doctrine of the Church as the Body of Christ.

The Greek theologian develops the doctrine by referring to the historical foundations of unity in the Eucharist, which has its roots in Old Testament times and is equivalent to the consciousness of the Jewish people. In the New Testament testimonies, Jesus in the context of the Eucharist was represented as a servant of God under the titles "Lord" and "Son of Man". Hence the dialectic established "one" and 
"many" that unites the Christian mystery "many" of the "other". Instead, "one" contains "many" - that is, the people of God. Due to this unity, J. Ziziulas considers it appropriate to use the term "corporate person" [17: 131].

In the ecclesiological Christology of $\mathrm{J}$. Ziziulas, Jesus is represented in the person of the incarnate Christ ("One") and Christ of the Church ("many"). Only in the sacrament of the Eucharist, according to the theologian, this distinction disappears. That is why the Eucharist occupies a central place in the ecclesiological Christology of J. Ziziulas.

A significant contribution to the interpretation of anthropological issues in the context of Orthodox theology was made by the modern Bishop of Diocletian Callist Ware. The main issues of Christology were reflected by the Metropolitan in triadology, pneumatology, ecclesiology and Mariology. The basic element of triadology is the doctrine of the absolute transcendence of God, His immanence, personality and three-hypostasis. The inner nature of divinity in Orthodoxy can be understood only apophatically: "God is not just one person limited by his own being, but a Trinity of Persons - the Father, the Son and the Holy Spirit each of whom is in the other two by the power of the eternal movement of love" [14: 218]. Callist Ware draws attention to the difficulty in the perception of representatives of different Christian traditions of the methods of cognition of Orthodox apophatic theology and problems of distinguishing between the essence of God and His energies while maintaining transcendence and immanence. At the same time, they worship the One God in three Persons and confess the incarnate Christ as the Son of God.

Callist Ware sees the incarnation of Christ, and therefore of God's Word, as an act of divine philanthropy, expressed in God's love and kindness to all mankind. The theologian shares the opinion of Maximus the Confessor that man was created for the sake of deification and this Divine purpose remained unchanged even after the fall. Therefore, incarnation must be considered as the main reason for God's creation of the world. Incarnation as a turning point in human history and worldview is also seen in Catholic theology. However, in Orthodox teaching, deification and redemption are analyzed as the only inseparable act in the general context of the doctrine of salvation. Through His atoning sacrifice, Christ prepared the way for people to overcome the negative effects of $\sin$, to be reconciled to God, and to be saved. As the atoning sacrifice of Jesus Christ, it testifies to God's perfect love for each of His creations.

The Orthodox doctrine of the nature and properties of the Church, according to Callist Ware, has a spiritual and at the same time mystical character. It is expressed in the unity of the Church as the Body of Christ, the presence of one Head of Jesus Christ, and the action of the Holy Spirit, who unites all Orthodox with Christ as its Head. Thus, the basis of ecclesiology is Christological and pneumatological ideas. The theologian notes: "The church is a continuation of the process of incarnation, a place where it continues" [14: 249]. By incarnating and becoming man, Christ gave birth to a new gracious people as the spiritual descendants of the Second Adam. The unity of the Church is the perfect and true gift of God for further spiritual growth.

Church unity is inextricably linked with the sacrament of baptism as the spiritual rebirth of man for eternal life in the Kingdom of God and the Eucharist, where believers are filled. Communion from the One Body of Christ, the Orthodox is truly united into a whole body, thanks to the love of Christ and the power of the Spirit. Callist Ware notes: "The church must be understood in sacramental terms. The external organization is second after ritual life" [14: 250].

An important aspect of ecclesiology, which is distinguished by Callist Ware, is pneumatology. According to the 
metropolitan, in the teaching and practice of modern Orthodoxy there is a dangerous tendency to neglect the role and place of the Holy Spirit in understanding the nature and properties of the Church [14: 250]. The theologian emphasizes the connection between Christology and pneumatology, which reveal the fullness of the righteous life and the depth of spiritual experience. Therefore, recourse to the Holy Father's tradition is an important request of today [18:56]. The unity of the life of grace lays the foundation for the inviolability of the church faith.

Metropolitan Callist Ware of Diocletian emphasizes that in addition to the divine foundation, there is also a human part in the Church, which was fixed by the dogma of Chalcedon. As Christ has a divine and human nature, so in the Church there is organized cooperation between the divine and the human. However, the difference between the human element in Christ and the Church is that the human nature of Christ is perfect and sinless, while in the Church it is wicked because of man's abuse of his freedom. This makes clear the Church's inner focus on fulfilling its mission to glorify God by engaging people in ministry. Thus, the Christological concept of Callist Ware was built in close connection with triadology, ecclesiology, pneumatology and mariology attesting to its originality in Orthodox theology.

\section{Conclusions and research}

perspectives. Thus, the development of modern research on anthropological issues in Orthodox theology is associated with a rethinking of the essence of man in accordance with the demands of today. Within the framework of Christological doctrine, the doctrine of man is reduced to the image and likeness of God, which reveals his nature, purpose of life and ways of salvation. Its understanding in the context of historical and modern trends, requires reference to the Holy Father's heritage. This caused the emergence of syncretic religious movements in the early Christian period, which expressed a dualistic interpretation of the person of Jesus Christ. This helps a person to overcome the theoretical limits of teaching, directing him to the knowledge of his true nature and leads to a revision of traditional approaches to the conditions of the rite and ceremony. Therefore, today there is a need to determine the anthropological content of paradigmatic transformations of modern Orthodox theology. It is also necessary to establish the possibilities of the influence of Christian doctrine of man on overcoming the anthropological crisis of our time. This approach in theology determines the view of the doctrine of man not only as theoretically significant, but also as a practical embodiment of the idea of godlikeness.

\section{LITERATURE}

1. Давыденков О. Догматическое Богословие: курс мекций. Ч. 1 и 2. Москва: ПСТГУ, 1997. 159 с.

2. Говорун К. COVID-19 та християнський (чи?) дуалізм [Електронний ресурс]. Режим доступу: https: / / cerkva.dp.ua/covid-19-tahristiyanskij-chi-dualizm/ (дата звернення: 10.04.2020).

3. Шафф Ф. История христианской церкви. Т. III: Никейское и посленикейское христианство. От Константина Великого до Григория Вемикого. СПб.: Библия дмя всех, 2007. 688 c.

4. Соколовський О. $\Lambda$. Сотеріологічний контекст христології гностицизму // Актуальні проблеми філософії та соціології. Науково-практичний журнал. 2017. Випуск 19. С. 116-119.

5. Писарев $\Lambda$. Очерки из истории христианского вероучения патристического периода: Век мужей апостольских (I и начало II в.). Казань: Центральная типография, 1915. 653 с.

6. Поснов М. Гностицизм второго века и победа христианской религии над ним. Киев, 1917; Брюссель: Жизнь с Богом, 1991. 828 с.

7. Алексанян А. "Учение света" в Китае: аспекты изучения этапов инкультурации // Труды "Русской Антропологической школы". 2009. № 6. С. 444-458. 
8. Хосроев А. История манихейства. СПб.: Филологический факультет СПбГУ, 2007. 428 с.

9. Тьерри А. Ересиархи V века Несторий и Евтихий. Минск: ИАьин, 2006. 448 с.

10. Антология восточно-христианской богословской мысли. Ортодоксия и гетеродоксия: В 2-х т. Т. 1. М., СПб.: "Никея"РХГА, 2009. 672 с.

11. Соколовський О. Христологічна проблематика Халкідонського собору // Вісник $\Lambda$ ьвівського університету. Філософсько-політологічні студії. Аьвів, 2018. Випуск 17. С. 87-94.

12. Деяния вселенских соборов, изданные в русском переводе при Казанской духовной академии: [в 7 т.]. Казань : в типографии Губернского правления, 1908. Т. 3. 283 с.

13. Зізіулас Й. Буття як спілкування. Дослідження особистості і церкви. К.: Дух і мітера, 2005. 276 с.

14. Уєр К. Православная церковь. М.: Библейско-Богословский Институт св. Апостола Андрея, 2001. 374.

15. Hovorun C. Ecumenism: Rapprochement Through Co-Working to Reconciliation. Religions. 2017. 5 (8). S. 70-77.

16. Rubskyi V. Communication Levels of the Individual. Anthropological Measurements of Philosophical Research 2019. 16. S. 24-32.

17. Афранасий

(Букин М. А.). Христологические основания экклезиологии митрополита Иоанна // Христианское чтение: научный журна. Санкт-Петербургская духовная академия. СПб. № 6: Теология. Фимософия. История. 2016. С. 128-138.

18. Вероучительные документы Православной Церкви. Москва: ДиректМедиа, 2011. 87 с.

\section{REFERENCES (TRANSLATED \& TRANSLITERATED)}

1. Davydenkov, O.

(1997).

Dogmaticheskoe Bogoslovie: kurs lekcij. Ch. 1 i 2. M.: PSTGU (in Russian).

2. Govorun, K. SOVID-19 ta hristiyanskij (chi?) dualizm [Elektronnij resurs]. Rezhim dostupu: https://cerkva.dp.ua/covid-19-tahristiyanskij-chi-dualizm/ (data zvernennya: 10.04.2020) (in Ukrainian).

3. Shaff, F. (2007). Istoriya hristianskoj cerkvi. T. III : Nikejskoe i poslenikejskoe hristianstuo. Ot Konstantina Velikogo do Grigoriya Velikogo. SPb.: Bibliya dlya vseh (in Russian).

4. Sokolovskij, O. (2017). Soteriologichnij kontekst hristologiyi gnosticizmu. Aktualni problemi filosofiyi ta sociologiyi. Naukovopraktichnij zhurnal, 19, 116-119 (in Ukrainian).

5. Pisarev, L. (1915). Ocherki iz istorii hristianskogo veroucheniya patristicheskogo perioda: Vek muzhej apostolskih (I i nachalo II v.). Kazan: Centralnaya tipografiya (in Russian).

6. Posnov, M. (1991). Gnosticizm vtorogo veka $i$ pobeda hristianskoj religii nad nim. Kiev; Bryussel: Zhizn s Bogom (in Russian).

7. Aleksanyan, A. (2009). "Uchenie sveta" v Kitae: aspekty izucheniya etapov inkulturacii. Trudy "Russkoj Antropologicheskoj shkoly", 6, 444-458 (in Russian).

8. Hosroev, A. (2007). Istoriya manihejstva. SPb.: Filologicheskij fakultet SPbGU (in Russian).

9. Terri, A. (2006). Eresiarhi $V$ veka Nestorij i Evtihij. Minsk: Ilin (in Russian).

10. Antologiya vostochno-hristianskoj bogoslouskoj mysli. Ortodoksiya $i$ geterodoksiya (2009). V 2-h t. T. 1. M., SPb.: "Nikeya"-RHGA (in Russian).

11. Sokolovskij, O. (2018). Hristologichna problematika Halkidonskogo soboru. Visnik Lvivskogo universitetu. Filosofsko-politologichni studiyi, 17, 87-94 (in Ukrainian).

12. Deyaniya vselenskih soborov, izdannye $v$ russkom perevode pri Kazanskoj duhounoj akademii (1908). Kazan: v tipografii Gubernskogo pravleniya, 3 (in Russian).

13. Ziziulas, J. (2005). Buttya yak spilkuvannya. Doslidzhennya osobistosti i cerkvi. K.: Duh i litera (in Ukrainian).

14. Uyer, K. (2001). Pravoslavnaya cerkov. M.: Biblejsko-Bogoslovskij Institut sv. Apostola Andreya (in Russian).

15. Hovorun, C. (2017). Ecumenism: Rapprochement Through Co-Working to Reconciliation. Religions. 5 (8). $70-77$ (in English).

16. Rubskyi, V. (2019). Communication Levels of the Individual. Anthropological Measurements of Philosophical Research, 16, 24-32 (in English).

17. Afanasij (Bukin M.). (2016). Hristologicheskie osnovaniya ekkleziologii mitropolita Ioanna. Hristianskoe chtenie: nauchnyj zhurna. Teologiya. Filosofiya. Istoriya, 6, 128-138 (in Russian).

18. Verouchitelnye dokumenty Pravoslavnoj Cerkvi. (2011). Moskva: DirektMedia (in Russian).

Receive: April 12, 2020 Accepted: May 20, 2020 